
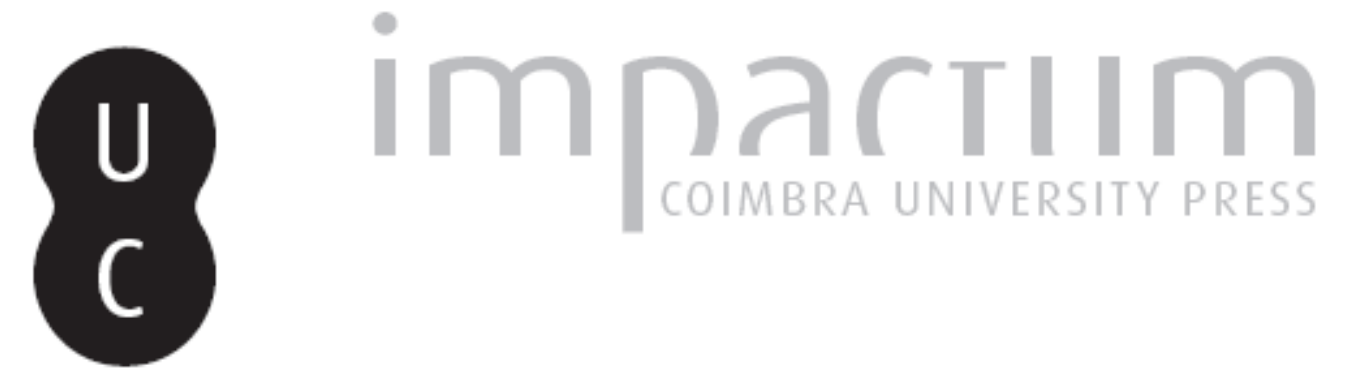

\title{
Processo inquisitorial e processo régio: semelhanças e diferenças (o caso português)
}

\author{
Autor(es): $\quad$ Faria, Ana Santiago de
}

Publicado por: Centro de História da Sociedade e da Cultura

URL

persistente:

URI:http://hdl.handle.net/10316.2/39394

DOI:

DOI:http://dx.doi.org/10.14195/1645-2259_13_12

Accessed : $\quad$ 26-Apr-2023 12:05:01

A navegação consulta e descarregamento dos títulos inseridos nas Bibliotecas Digitais UC Digitalis, UC Pombalina e UC Impactum, pressupõem a aceitação plena e sem reservas dos Termos e Condições de Uso destas Bibliotecas Digitais, disponíveis em https://digitalis.uc.pt/pt-pt/termos.

Conforme exposto nos referidos Termos e Condições de Uso, o descarregamento de títulos de acesso restrito requer uma licença válida de autorização devendo o utilizador aceder ao(s) documento(s) a partir de um endereço de IP da instituição detentora da supramencionada licença.

Ao utilizador é apenas permitido o descarregamento para uso pessoal, pelo que o emprego do(s) título(s) descarregado(s) para outro fim, designadamente comercial, carece de autorização do respetivo autor ou editor da obra.

Na medida em que todas as obras da UC Digitalis se encontram protegidas pelo Código do Direito de Autor e Direitos Conexos e demais legislação aplicável, toda a cópia, parcial ou total, deste documento, nos casos em que é legalmente admitida, deverá conter ou fazer-se acompanhar por este aviso.

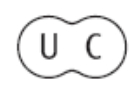



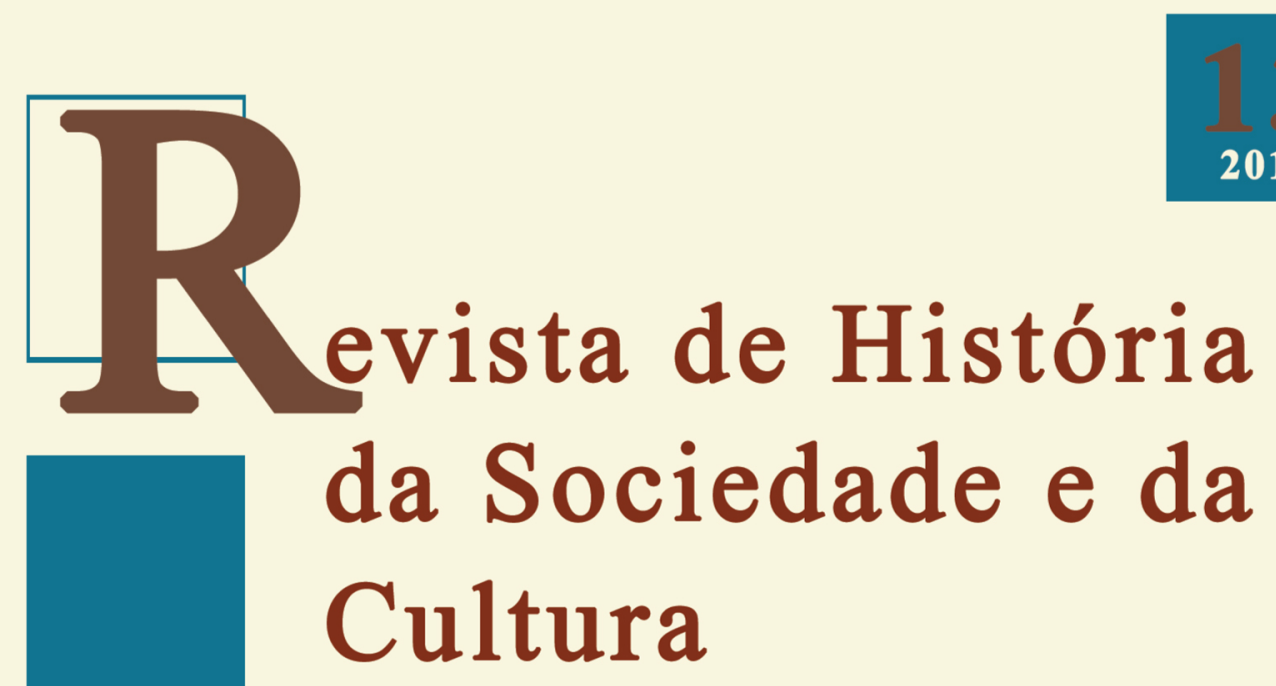

2013

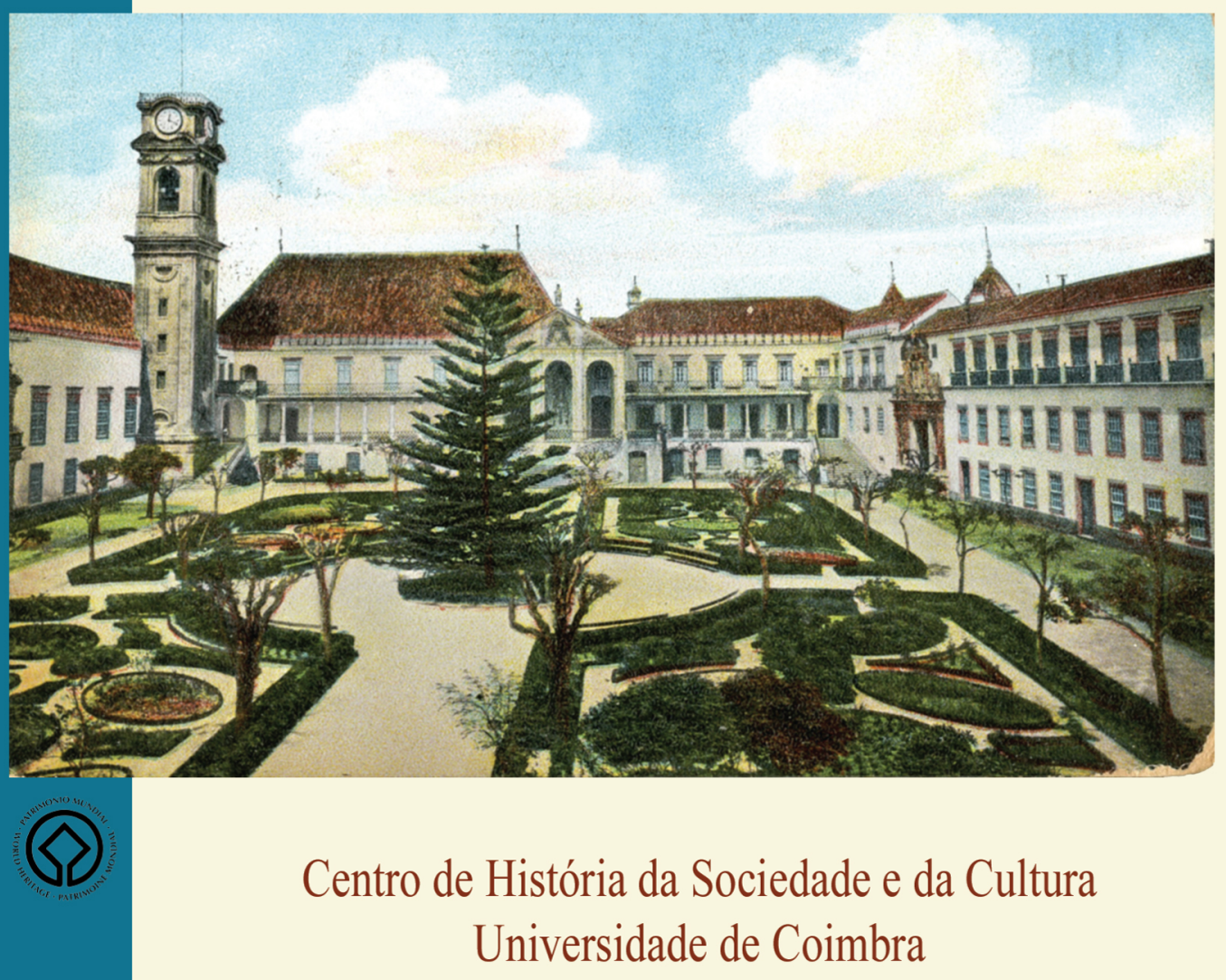

Coimbra 


\title{
Processo inquisitorial e processo régio: semelhanças e diferenças (o caso português)
}

\author{
Ana Santiago de Faria \\ Universidade de Coimbra \\ anasantiagofaria@gmail.com \\ Texto recebido em /Text submitted on: 28/05/2013 \\ Texto aprovado em /Text approved on: 19/11/2013
}

\section{Resumo/Abstract:}

O processo inquisitorial foi um dos aspetos mais polémicos da História da Inquisição. Alvo preferencial das críticas dos cristãos-novos, que alegavam a especificidade do procedimento português, é ainda hoje considerado pela historiografia como um procedimento de natureza excecional.

Partindo da premissa que um correto entendimento do processo inquisitorial passa por enquadrá-lo como parte da cultura jurídica europeia de que é originário, propõe-se um estudo comparativo entre o processo praticado no Tribunal do Santo Ofício Português, tal como consagrado no Regimento do Santo Ofício de 1640, com o direito processual penal secular, regulado nas Ordenações Filipinas.

Através de uma análise comparativa que autonomiza, por um lado, a marcha do processo, por outro, a teoria da prova, pretende-se aferir quais as semelhanças e diferenças existentes entre as duas justiças, nomeadamente se institutos e práticas jurídicas similares possuíam a mesma natureza, enquanto normas gerais ou excecionais.

The Inquisitorial Process was one of the most controversial aspects of the History of the Inquisition. Main target of criticism by the New Christians, who claimed the uniqueness of the Portuguese procedure, it is still today regarded by the historiography as a procedure of exceptional nature.

Considering that a correct understanding of the Inquisitorial process envolves framing it within the european law culture from which it derives, this paper proposes a comparative study between the procedures practiced by the Portuguese Tribunal of Holy Office, as enshrined by the 1640s Regimento do Santo Oficio, and those practiced by the Secular courts, regulated by the Ordenações Filipinas.

Through a comparative analysis that on one hand empowers the conduct of proceedings, and on the other, the proof theory, we aim to assess the similarities and differences between the two legal institutions, namely assessing if similar legal institutions and practices had the same nature, as general or exceptional rules.

Palavras chave/Keywords:

Processo inquisitorial; Processo penal secular; Processo Penal.

Inquisitorial process; Secular courts process; Criminal procedure.

* Agradeço ao Prof. Doutor José Pedro Paiva a revisão e os comentários feitos a este artigo. 
“Todo o processo (...) permanecia secreto, até à sentença: ou seja, opaco não só para o público, mas para o próprio acusado (...) impossivel ter acesso às peças do processo, impossivel conhecer a identidade dos denunciantes, impossível saber o sentido dos depoimentos (...)"'

Com estas palavras de Michel Foucault, através das quais descreveu o processo criminal francês na Época Moderna, não se pretende mais do que chamar a atenção para o seguinte: que práticas comummente associadas ao Tribunal da Fé não eram estranhas a outras jurisdições penais, e mais especificamente às seculares. Porém, a analogia entre os dois processos, cuja origem se encontra na utilização de um mesmo modelo processual - o inquisitivo - tem os seus limites e não equivale a uniformidade de procedimentos ${ }^{2}$.

O tema deste estudo surgiu dessa constatação e do equacionar de algumas questões que creio fundamentais, entre as quais saliento: aferir da existência de institutos e práticas judiciais similares às duas jurisdições e se essas figuras jurídicas, quando análogas, possuíam a mesma natureza, enquanto normas gerais ou excecionais. Para tanto, propõe-se uma análise comparativa que autonomiza, por um lado, a marcha do processo; por outro, a teoria da prova.

É necessário, no entanto, delimitar o alcance da comparação proposta. Temporalmente visa o século XVII e as primeiras décadas do século XVIII. No processo inquisitorial, o enfoque incidirá nas causas contra os denunciados $^{3}$. No foro secular, a realidade é mais complexa. As Ordenações Filipinas previam um processo comum que podia seguir uma estrutura mais próxima do modelo acusatório ou um modelo mais acentuadamente inquisitivo, conforme existisse ou não querela e acusação de parte. Ao lado desse processo comum existiam formas processuais sumárias, que não se

1 FOUCAULT, Michel - Vigiar e Punir: nascimento da Prisão. Petrópolis: Editora Vozes, 2007, p. 37.

2 Sobre a origem e o desenvolvimento do processo inquisitivo, veja-se a síntese de PIFFERI, M. - Diritto comune e inquisitio ex officio in PROSPERI, A. (ed.) - Dizionario Storico dell'Inquizione. Pisa: Edizioni della Normalle, 2010, Vol. I, p. 492-495.

3 Por se revestir de uma natureza diferente, mais próxima do foro penitencial, o processo dos apresentados não será abordado. 
encontravam regulamentadas e que eram seguidas em dois casos: nos crimes leves e nos delitos mais gravosos ${ }^{4}$. No que toca ao foro secular abordar-se-á, por um lado, o processo comum ex officio, e não o fundado em querela e acusação de parte; por outro lado, o processo sumário nos crimes gravosos.

No que respeita às fontes utilizadas, cabe fazer duas advertências. Em primeiro lugar, e no que toca ao foro secular, salientam-se as restrições que a ausência de processos acarreta, obrigando, na análise da marcha processual do processo comum, à circunscrição das fontes, às Ordenações e à doutrina ${ }^{5}$; este obstáculo é ainda mais premente na forma sumária, dado não se encontrar sequer regulamentada ${ }^{6}$. Em segundo lugar, e no que se refere à teoria da prova, considero que ao contrário da marcha processual, tanto a lei, como sobretudo a doutrina, constituem fontes privilegiadas para o seu estudo, uma vez que os processos concretos dificilmente permitem inferir o complexo sistema em que assentavam as decisões judiciais.

4 Ver FREIRE, Pascoal de Melo - Instituições de Direito Criminal Português. Boletim do Ministério da Justiça. 155 e 156 (1966); SOUSA, Joaquim José Caetano Pereira - Primeiras Linhas sobre o Processo Criminal. Lisboa: Officina de Simão Thaddeo Ferreira, 1800, p. 25.

5 A ausência de processos explica em grande parte a escassez de trabalhos historiográficos neste campo; os poucos que se conhecem têm como fontes as Ordenações e a doutrina, como é o caso do estudo de ALBUQUERQUE, Paulo Pinto de - A Reforma da Justiça Criminal em Portugal e na Europa. Coimbra: Almedina, 2003, p. 25-73. Existem alguns estudos locais baseados predominantemente nos perdões de parte que, embora tenham importantes contribuições para o estudo do processo penal, refletem uma realidade jurisdicional - local e no campo dos delitos privados - que não é a aqui visada; uma síntese da principal bibliografia nessa matéria pode ser vista em NETO, Margarida Sobral - "Violências do quotidiano" in O universo da comunidade rural, Coimbra: Palimage, 2010.

6 Para o estudo do processo sumário recorreu-se à obra de Álvares Pegas que reconstituiu três processos-crime instaurados na sequência do crime do Senhor Roubado da Igreja de Odivelas; Álvares Pegas interveio nesses processos na qualidade de advogado de defesa e como tal foi um observador privilegiado, não só descreveu com detalhe os passos fundamentais dos processos, como transcreveu grande parte dos autos: PEGAS, Manuel Álvares - Tratado Historico, e Juridico sobre o Sacrilégo Furto, Execravel Sacrilegio que se fez em Parochial Igreja de Odivelas, Termo da Cidade de Lisboa, na noyte de dez para onze do Mez de Mayo de 1671. Madrid: oficina Roque de Miranda, 1678. 


\section{A marcha do processo}

\section{O Processo secular comum ex officio}

A ação penal ex officio iniciava-se com a instauração de uma devassa, que mais não era do que uma inquirição geral que visava a obtenção de informações. Com origem, quer em denúncia, quer em "qualquer notícia ou informação", as devassas tinham um limite: apenas ocorriam nos casos consignados na lei ${ }^{7}$. Encontravam-se previstas duas espécies: as gerais e as especiais, podendo ambas culminar na formação do corpo do delito ${ }^{8}$. Em que situações?

Em primeiro lugar, era necessário que das informações recolhidas nas devassas tivesse resultado a identificação de um determinado delito, bem como do seu presumível autor. Porém, da natureza dos crimes, decorria uma importante distinção doutrinal: ao lado do corpo do delito direto que deixava vestígios, podendo formar-se para além dos testemunhos, por observação ocular - configurava-se o corpo do delito indireto, formado pelo exame das testemunhas, por conjeturas e presunções ${ }^{9}$. Com base no corpo do delito, procedia-se ao despacho de pronúncia e daí a importância que a doutrina dava à sua configuração, não sendo suprível nem com a confissão do réu ${ }^{10}$.

7 LEITÃO, Mateus Homem - Do Direito Lusitano: dividido em três tratados: Agravos, Cartas de Seguro, Inquirições. Lisboa: Fundação Calouste Gulbenkian, 2009 (edição original em latim de 1645), p. 393. Quanto à admissibilidade das denúncias anónimas, ver FREIRE, Pascoal de Melo - Instituições de Direito..., cit., (156), p. 100-102; e Livro V, Titulos: 2 (blasfémia); 6 (lesa-majestade); 12 (moeda falsa); 13 (sodomia, bestialidade e molície), Ordenações Filipinas, Edição «fac-simile» da edição feita por Cândido Mendes de Almeida, Rio de Janeiro, 1870. Lisboa: Fundação Calouste Gulbenkian, 1985 (adiante designadas apenas por Ord. Fil.).

8 As devassas gerais visavam delitos incertos, mas crimes específicos e em alguns casos pessoas determinadas; as especiais visavam delitos certos, podendo o autor ser conhecido ou não (Ord. Fil., Livro I, Tit. 65, §31-33; §39-72). Ver LEITÃO, Mateus Homem Do Direito Lusitano..., cit., p. 371-553.

9 Ver CABRAL, António Vanguerve - Pratica Judicial..., cit., p. 256-257; SOUSA, Joaquim José Caetano Pereira - Primeiras Linhas ..., cit., p. 12; FREIRE, Pascoal de Melo - Instituições de Direito Criminal..., cit., (156), p. 96-97.

${ }^{10}$ SOUSA, Joaquim José Caetano Pereira-Primeiras Linhas ..., cit., p. 11; FERREIRA, Manuel Lopes - Pratica Criminal..., cit., Tomo II, p. 8; CABRAL, António Vanguerve Pratica Judicial..., cit., p. 255-256. 
No despacho de pronúncia, onde o suspeito era constituído réu no processo, decidia-se da prisão ou do livramento do réu pronunciado, sendo que esta última hipótese apenas ocorria nos casos de delitos "muito leves"11. Diga-se, igualmente, que era neste momento, e se da pronúncia resultasse que o réu "merecesse ser preso", que se procedia ao sequestro de bens, caso o delito estatuísse a pena de confisco ${ }^{12}$.

Para lá das considerações relativas à prova que o despacho de pronúncia levanta, cabe aqui levantar três importantes questões, antes de passar à segunda fase do processo.

Quando podia o réu ser preso? A prisão antes da culpa formada, isto é, antes da pronúncia, era permitida em dois casos: em "flagrante delito" e em todos os delitos que "provados merecessem morte natural" (que eram muitos!). Atente-se, no entanto, que em ambos os casos se previam prazos curtos para o encarceramento sem culpa formada ${ }^{13}$. Se eram ou não cumpridos é outra questão ${ }^{14}$.

A prisão do réu era uma prática comum? Não sendo possível, por falta de dados, responder a esta questão, é importante referir que existiam diversas figuras que evitavam o encarceramento do réu, entre as quais cabe destacar as cartas de seguro ${ }^{15}$. Figura do direito pátrio que tinha uma aplicação vasta e que, grosso modo, evitava o encarceramento do réu, ficando este obrigado

${ }^{11}$ LEITÃO, Mateus Homem - Do Direito Lusitano..., cit., p. 393 e segs.; FREIRE, Pascoal de Melo - Instituições de Direito Criminal..., cit., p. 104-105.

${ }^{12}$ Ord. Fil., Livro V, Tit. 126, §11. Entre os crimes que previam a pena de confisco: Tit. 1 (heresia); Tit. 6 (lesa-majestade); Tit. 12 (moeda falsa); Tit. 13 (sodomia).

${ }^{13}$ A expressão "flagrante delito" é usada por Pereira e Sousa, mas não deixa de ser sui generis, dado que a ordenação possibilita ao juiz se "parecer que são culpados" a prisão até seis pessoas - Ord. Fil., Livro I, Tit. 65, §37. Ver SOUSA, Joaquim José Caetano Pereira Primeiras Linhas..., cit., p. 15. O outro caso a que se alude no texto resulta da lei da reforma da justiça de 6 de Dezembro de 1612, §14. Tanto o texto da lei como um comentário ao seu teor podem ser vistos em CABRAL, António Vanguerve - Pratica Judicial..., cit., p. $107-155$.

${ }^{14}$ António Manuel Hespanha refere que nos dados que analisou se encontram "não poucos casos de indivíduos detidos à ordem de qualquer entidade (...), sem qualquer acusação precisa“". Cf. HESPANHA, António Manuel - Da «Institia» à «Disciplina». Separata do Boletim da Faculdade de Direito da Universidade de Coimbra. Estudos em homenagem ao Prof. Doutor Eduardo Correia. Coimbra: s.n., 1986, p. 32.

${ }^{15}$ Refira-se igualmente a homenagem e a fiança, Ord. Fil., Livro V, Tit. 120; Tit. 131. Ver FREIRE, Pascoal de Melo - Instituições de Direito Criminal..., cit., (156), p. 110-117; CABRAL, António Vanguerve - Pratica Judicial..., cit., p. 267. 
a comparecer em juízo sob pena de ser preso se não o cumprisse ${ }^{16}$. A sua admissibilidade era tal que mesmo perante delitos de extrema gravidade era admitida ${ }^{17}$. A única exceção: o crime de lesa-majestade, assim o referia Mateus Homem Leitão, "nunca vi ou ouvi que são concedidas cartas de seguro, nem o uso admitiu"18.

A terceira pergunta prende-se com o momento da inquirição do réu. Quando era o réu inquirido e qual o objetivo dessa inquirição?

Não resulta claro o momento da inquirição do réu nem das ordenações, nem da doutrina ${ }^{19}$. Não tenho dúvidas que a inquirição poderia ocorrer ao longo de todo o processo, mas com efeitos distintos: durante a inquirição-devassa e até à pronúncia, a inquirição era considerada extrajudicial, sem valor probatório, por isso tinha que ser repetida logo após a pronúncia - se daí resultasse a prisão do réu -, ou após a acusação, já na fase probatória do processo $^{20}$.

Quanto ao objetivo dessa inquirição radicava na obtenção da confissão, à volta da qual "todo o mecanismo processual gira"21.

$\mathrm{Na}$ segunda fase do processo, que consistia no julgamento da causa, distinguem-se três partes: a fixação da lide, a fase probatória e a prolação da sentença.

A fixação da lide, isto é, a definição da questão judicial e da postura das partes no processo, resultava dos articulados admitidos. Iniciava-se com a apresentação da acusação ou libelo da justiça, devendo-se nela narrar

${ }^{16}$ Ord. Fil., Livro V, Tit. 129. Sobre as cartas de seguro e a complexidade que revestiam, ver LEITÃO, Mateus Homem - Do Direito Lusitano..., cit., p. 213-368; FREIRE, Pascoal de Melo - Instituições de Direito Criminal..., cit., (156), p. 118-125.

${ }^{17}$ Ord. Fil., Livro I, Tit. 7; §8.

${ }^{18}$ LEITÃO, Mateus Homem - Do Direito Lusitano..., cit., p. 284.

${ }^{19}$ Ord. Fil., Livro III, Tit. 32, pr.; §1 e 3. Ver CABRAL, António Vanguerve - Pratica Judicial..., cit., p. 259; FREIRE, Pascoal de Melo - Instituições de Direito Criminal..., cit., (156), p. 132.

${ }^{20}$ Veja-se SOUSA, Joaquim José Caetano Pereira - Primeiras Linhas..., cit., p. 41; FREIRE, Pascoal de Melo - Instituições de Direito Criminal..., cit., (156), p. 131. Uma realidade similar em Castela é descrita por ALONSO ROMERO, María Paz - El Proceso Penal en Castilla (Siglos XIII-XVIII). Salamanca: Universidad Salamanca, 1982, p. 209.

${ }^{21}$ ALONSO ROMERO, María Paz - El Proceso Penal ..., cit., p. 205 (tradução minha). Sobre o modo como o juiz devia atuar no interrogatório, ver FERREIRA, Manuel Lopes Pratica Criminal..., cit., Tomo II, p. 4-8. 
o delito e suas circunstâncias, determinando-se o seu tempo e lugar ${ }^{22}$. Ainda antes de o réu responder ao libelo, apresentando a contrariedade, podia alegar exceções ${ }^{23}$. Na contrariedade ou contestação do réu, objetavam-se diretamente os artigos da acusação; se aceite, era dado prazo ao réu (dilação) para nomear testemunhas para prova dos artigos apresentados ${ }^{24}$.

Dava-se assim início à fase probatória. Para além da inquirição das testemunhas apresentadas pelo réu, tinha lugar nesta fase a reinquirição das testemunhas da justiça, dado que os depoimentos colhidos na devassa eram considerados extrajudiciais e por regra não constituíam prova. Quando ocorriam e como se processavam?

Não havia lugar à reinquirição em dois casos. Primeiro, quando o réu assinasse o "termo de judiciais" conferindo validade aos depoimentos ${ }^{25}$. Em segundo lugar, quer o depoimento das testemunhas ausentes, quer o das testemunhas já falecidas, dada a impossibilidade de serem reinquiridas, tinham-se por judiciais ${ }^{26}$.

Quanto ao modo como se processavam as inquirições é necessário distinguir dois momentos: o juramento e o depoimento ${ }^{27}$. Ao juramento o réu assistia, devendo ser citado para esse fim, sob pena de nulidade; já a inquirição, propriamente dita, era secreta ${ }^{28}$.

Findas as inquirições das testemunhas, o réu poderia, se entendesse, apresentar contraditas que visavam atacar a admissibilidade de determinadas

${ }^{22}$ Ord. Fil., Livro V, Tit. 124, pr. Ver SOUSA, Joaquim José Caetano Pereira-Primeiras Linhas..., cit., p. 32.

${ }^{23}$ Ord. Fil., Livro V, Tit. 124, pr.; Livro III, Tit. 49, §2. As exceções dilatórias ou peremptórias estavam reguladas nas Ord. Fil., Livro 3, Tit. 49 e 50 e distinguiam-se conforme diferiam (entre estas, o incidente de suspeição do juiz, a incompetência do foro) ou extinguiam a ação (entre estas, a prescrição e o caso julgado).

${ }^{24}$ Ord. Fil., Livro V, Tit. 124, pr., §1 e 2; Livro III, Tit. 54; Tit. 55, §2 (número de testemunhas admitidas).

${ }^{25}$ Termo que era feito durante a dilação dada para a contrariedade. Ver Lei da reformação da justiça de 6 de Dezembro de 1612, §18. A este propósito veja-se Mateus Homem Leitão que referenciava alguns abusos por parte dos juízes que forçavam os réus a fazer o termo de judiciais. LEITÃO, Mateus Homem - Do Direito Lusitano..., cit., p. 551-552.

${ }^{26}$ Ord. Fil., Livro III, Tit. 62, §1. LEITÃO, Mateus Homem - Do Direito Lusitano..., cit., p. 553. Com uma opinião diferente, FREIRE, Pascoal de Melo - Instituições de Direito Criminal..., cit., (156), p. 129-130.

${ }^{27}$ As regras gerais relativas à inquirição das testemunhas encontram-se nas Ord. Fil., Livro I, Tit. 86.

${ }^{28}$ Ord. Fil., Livro III, Tit. 1, §13; Livro I, Tit. 86, pr.; e Livro III, Tit. 62, §1. 
pessoas como testemunhas e não o teor do seu depoimento que, o réu, nessa data, desconhecia ${ }^{29}$. Se fossem relevantes, o juiz assinava termo breve para que se procedesse à sua prova ${ }^{30}$.

Finda a produção de prova, as inquirições eram abertas e publicadas, para que o réu alegasse de direito. Atente-se, no entanto, que tal apenas ocorria nos casos em que o réu estivesse preso, isto é, estando o réu livre ou seguro, "ser-lhe-ha dada vista do feito, com as inquirições e razões do acusador cerradas e selladas" 31 .

Nos delitos de sodomia, bestialidade e molície, o juiz - a seu arbítrio poderia não só manter as inquirições cerradas e seladas, como ocultar o nome das testemunhas aos réus ${ }^{32}$.

Dando-se por encerrado o período probatório, o processo era concluso para que se aferisse do eventual uso do tormento ou para que se lavrasse sentença $a^{33}$.

Acrescente-se que, ao longo de todo o processo, eram admitidos diversos recursos. Para além do incidente de suspeição do juiz, era admitido recurso de agravo de todas as decisões interlocutórias, nomeadamente, dos despachos de: pronúncia, tormento e recusa das contraditas; também a falta de juramento das testemunhas e a sentença final conheciam recurso de agravo. A apelação tinha necessariamente lugar nos feitos crime julgados em primeira instância ${ }^{34}$.

${ }^{29}$ Ord. Fil., Livro V, Tit. 124, §4 e Livro III; Tit. 58, pr., §2 e 4 (número de testemunhas admitidas).

${ }^{30}$ SOUSA, Joaquim José Caetano Pereira - Primeiras Linhas ..., cit., p. 40.

${ }^{31}$ Ord. Fil., Livro V, Tit. 124, §5.

32 Ord. Fil., Livro V, Tit. 13, §7.

${ }^{33}$ Sobre a sentença e sua execução, veja-se SOUSA, Joaquim José Caetano Pereira - Primeiras Linhas..., cit., p. 48-58; FREIRE, Pascoal de Melo - "Instituições de Direito Criminal..., cit., (156), p. 147-156.

${ }^{34}$ Sobre os recursos e as diferenças entre apelação e agravo, ver LEITÃO, Mateus Homem - Do Direito Lusitano..., cit., p. 5-212. 


\section{O processo sumário no foro secular}

Melo Freire é quem, com mais detalhe, trata do processo sumário, que tal como referido não se encontra regulado nas Ordenações ${ }^{35}$. Para o jurista, não se exigiam solenidades nesta forma de processo, mas devia obrigatoriamente constar: o corpo do delito, os depoimentos das testemunhas, o interrogatório do réu, suas respostas e tudo o mais que seja "exigido pelo direito natural para a defesa dos réus". Acrescentava ainda que não se podiam omitir as "partes substanciais do processo", isto é, a possibilidade de recurso, a contradita das testemunhas e o seu reexame ${ }^{36}$. Seria assim?

Para que se possa responder a esta questão proponho-me, a partir da obra de Manuel Álvares Pegas relativa ao crime do Senhor Roubado, na Igreja de Odivelas, analisar os três processos-crime julgados na Casa da Suplicação, que o jurista reconstituiu, tendo neles intervindo na qualidade de advogado de defesa ${ }^{37}$.

Na sequência do crime da Igreja paroquial de Odivelas ocorrido na noite de 10 para 11 de Maio de 1671, foi ordenada devassa para que "se fizesse nele toda a demonstração" 38 .

Decorria a devassa, quando, a 25 de Junho, foi enviada para Lisboa carta provinda do chantre da Sé da Guarda, dando conta que um João Rodrigues havia denunciado seu irmão, Manuel Mendes Soares, bem como quatro indivíduos residentes em Lisboa, a mando de quem Manuel Mendes Soares praticara o dito sacrilégio. Enviava-se carta com a denúncia.

${ }^{35}$ Não encontrei na doutrina nenhum autor que explicitasse com clareza como se estruturava o processo sumário; note-se que Melo Freire não indicava o que era o processo sumário, mas o que devia ser essa forma processual, no seu entender. Também Maria Paz Alonso fala de idêntica realidade para o caso de Castela; o seu estudo possui uma boa síntese para se entender a origem da forma sumária, ver ALONSO ROMERO, María Paz - El Proceso Penal..., cit., p. 287-315.

${ }^{36}$ FREIRE, Pascoal de Melo - Instituições de Direito Criminal..., cit., (156) p. 79-80 e 108-109.

${ }^{37}$ PEGAS, Manuel Álvares - Tratado Historico..., cit.. Chame-se a atenção para a obra de autoria de Jorge Martins, onde se trata os processos-crime referidos na reconstituição de Álvares Pegas - fonte usada pelo historiador - como se tivessem sido julgados no Tribunal da Fé. Trata-se de um erro, como se poderá ver no seguimento deste artigo (veja-se em especial a defesa de António Ferreira por Álvares Pegas). Martins, Jorge-O senhor Roubado, a Inquisição e a Questão Judaica. Póvoa de Santo Adrião: Europress, 2002.

${ }^{38}$ PEGAS, Manuel Álvares - Tratado Historico..., cit., p. 61 e 65. 
Em 27 de Junho, o regedor das justiças e os demais juízes nomeados, ordenaram a prisão de todos os intervenientes, denunciante e denunciados, para que se fizessem as "perguntas convenientes" 39 .

A 11 de Agosto em acórdão da Relação, os desembargadores decidiram que "para que na prisão não se dilatassem os presos mais de 10 dias (...) vistas "as testemunhas, \& papéis juntos, perguntas,\& mais diligências, não resulta culpa" contra os denunciados e ordena que saiam em liberdade. Quanto ao denunciante, João Rodrigues, mandam que os autos se façam sumários, com parecer do senhor regedor, e que "diga de feyto, $\&$ de direito em termo de cinco dias" ${ }^{40}$. Nomeiam-lhe como defensor Álvares Pegas ${ }^{41}$.

Não cabe aqui tratar do conteúdo da defesa de Pegas, mas apenas chamar a atenção para dois aspetos. Primeiro, resulta da defesa que o advogado teve acesso aos autos e a todo o seu conteúdo. Segundo, que a defesa consistiu em alegações de facto e de direito. A 17 de Agosto foi proferida sentença, condenando-se o réu João Rodrigues, por jurar falso em juízo, “que pelas ruas públicas, \& costumadas seja (...) publicamente açoitado com baraço e pregão, \& que vá degradado por tempo de dez anos para S.Thomé”. Na sentença é dado o prazo de 24 horas para que o réu deduzisse embargos. Foram rejeitados e a sentença executou-se ${ }^{42}$.

O segundo processo-crime contra Maria dos Santos é em tudo similar e também aqui o "feitiço se vira contra o feiticeiro"; Maria dos Santos denunciante, transforma-se em ré por falso testemunho. Como única diferença, a confissão da ré. O processo foi breve, apenas nove dias decorreram entre o acórdão que ordena os autos sumários e a sentença. Diga-se que esta é novamente exemplar, açoites e degredo por quatro anos para Castro Marim ${ }^{43}$.

O terceiro processo-crime foi movido contra António Ferreira que veio a ser condenado pelo crime de furto e sacrilégio. António Ferreira foi preso e inquirido a 17 de Outubro de 1671, tendo-se encontrado uma cruz de prata

${ }^{39}$ Idem, p. 76.

${ }^{40}$ De acordo com as ordenações cabia ao regedor da Casa da Suplicação a decisão de "proceder sumariamente (...) vista a qualidade do caso, e prova, e todo bem considerado", Ord. Fil., Livro I, Tit. 1, §16.

${ }^{41}$ Idem, p. 76-77

${ }^{42}$ Idem, p. 78-101.

${ }^{43}$ Idem, p. 103-117. 
entre os seus pertences ${ }^{44}$. Se primeiro afirmou que tinha acompanhado dois homens que desconhecia, veio mais tarde a negar a coautoria, confessando ter cometido o crime sozinho. Em 18 de Outubro havendo dúvidas se o réu devia ser posto a tormento "para descobrir cúmplices" foram nomeados mais juízes ${ }^{45}$. No dia seguinte, mandou-se que os autos fossem conclusos para sentença, sem se fazerem diligências no tormento. Foi então ordenado que o processo se fizesse sumário e dada a prova existente foram concedidas 24 horas para defesa ${ }^{46}$.

O acórdão de 19 de Outubro, que decidiu não dar tratos ao réu, viria a ser embargado quer pelo promotor da justiça, quer pelo procurador da corte; requereram estes - em embargos separados - que se desse tormento ao réu vista a impossibilidade de aquele ter cometido o crime sozinho, apontando-se uma série de diminuições na confissão do réu. A 12 de Novembro era emitido o acórdão relativo aos embargos, que decidia pela sua procedência parcial. Ordenava-se que o réu "seja metido a tormento em cabeça alhea para declarar os sócios, para o que se lhe dá três tratos espertos" ${ }^{\text {"47 }}$.

António Ferreira acabaria por nomear alguns nomes no tormento, vindo porém a retratar-se na ratificação. Mas, dado que havia declarado o paradeiro das "meyas do menino jesus", uma das suas diminuições, foram as diligências consideradas suficientes e dado o prazo de três dias, "visto o que mais acresceu" para alegações. Pegas alegou mais uma vez de facto e de direito, mas iniciou a sua defesa aduzindo a exceção do foro. No seu parecer o crime em causa não era mixti fori, sendo sim da competência do foro inquisitorial, dado que "resulta contra ele presunção de sentir mal contra nossa Fé Catholica"; acrescentava que, "não se deve considerar que he mais conveniente ser o reo castigado no foro secular" uma vez que o Santo Ofício "castiga com brandura”, não deixando, no entanto, de apontar

${ }^{44}$ No mesmo dia da inquirição foram ouvidos dois ourives que comprovaram que a cruz era pertença de um vaso que se encontrava na Igreja. Idem, p. 69.

${ }^{45}$ Os processos sumários eram vistos em Mesa, sendo esta constituída por seis desembargadores, porém, caso o regedor entendesse poderiam ser nomeados mais juízes. Ord. Fil., Livro 1, Tit. 1, $\S 6$ e 16.

${ }^{46}$ PEGAS, Manuel Álvares - Tratado Historico..., cit., p. 118-119.

${ }^{47}$ Idem, p. 120-132. Os embargos eram apenas procedentes quanto ao tormento, não quanto a outras diligências de prova que se requereram, como foi o caso da averiguação sobre os parentes do réu "porque pode ser herege" (embargo do procurador da corte, p. 129). 
que no Tribunal da Fé "semelhantes delinquentes" são igualmente relaxados à justiça secular. De seguida, alegava-se sobre o mérito da causa, pedindo-se a condenação do réu em pena extraordinária, tendo em conta a idade (19 anos), confissão espontânea, "simplicidade, ignorancia, \& bebedice", factos que excluíam o dolo ${ }^{48}$.

A sentença foi proferida em 20 de Novembro de 1671, pouco mais de um mês havia passado sobre a data da prisão de António Ferreira. Em 23 de Novembro foram rejeitados os embargos interpostos pelo réu e no mesmo dia executou-se a sentença, onde se impunha: “ havendo porém respeito a ser o reo hum homem rustico, bárbaro, de pouco juízo, o condenam somente, a que com baraço, \& pregão pelas ruas publicas, \& costumadas seja arrastado, \& levado à praça do rocio (...) onde lhe serão decepadas ambas as mãos, $\&$ queimadas à sua vista, \& depois seu corpo será queimado, \& feito por fogo pó, para que delle não haja memória, \& o condenam (...) em perdimento, \& confiscação de todos os seus bens" ${ }^{\prime 4}$.

Ressalvando o carácter residual, bem como a exemplaridade da punição, dos crimes acima referidos, que conclusões se podem $\operatorname{tirar}^{50}$ ?

Creio que resulta evidente que a forma sumária reduzia a formalidade ao mínimo em prol da celeridade, estabelecendo-se os prazos ao arbítrio do juiz. Não só se condensa numa só fase o inquérito e a acusação, daí resultando que o despacho de pronúncia e o libelo da justiça surjam fundidos num só ato formal, como, não existindo verdadeiramente uma etapa de fixação da lide - não se inferindo qualquer sinal de contraditório - também a prova se produz nessa grande fase, sendo legítimo perguntar se havia lugar ao reexame das testemunhas e a contraditas.

Quanto ao reexame das testemunhas, a sua inexistência é manifesta, dado que a fase probatória não tem autonomia; o que não quer necessariamente dizer que o réu não pudesse ser citado para o juramento das testemunhas. É certo que a defesa do réu era extensa e com fundamentos de facto e de direito, e que a prova da justiça era "aberta e publicada", sendo a sentença recorrível; porém, não só se condensam num só ato os vários passos que

${ }^{48}$ Idem, p. 133-167.

${ }^{49}$ Idem, p. 171.

${ }^{50}$ Para um estudo sobre a litigiosidade na Idade Moderna, ver HESPANHA, António Manuel - Da «Institia» à «Disciplina» ..., cit. 
aquela revestia na forma comum - dedução de exceções, contrariedade e alegações de direito - como resulta claro que a fase probatória já tinha terminado, não se vendo como poderia o réu apresentar prova para defesa ou contraditas. A fazê-lo, teria que ser antes do despacho que faz os autos sumários, em condições que não se conseguem apurar.

\section{A marcha do processo inquisitorial}

O juízo inquisitorial iniciava-se com origem em denúncia, não sendo admitido o anonimato. Esta é a regra, mas, como era usual, tinha exceção: salvo se parecesse "que convém ao serviço de Deus"

Iniciava-se assim uma primeira fase de inquérito, em que os depoimentos eram tomados, podendo igualmente ocorrer outras diligências conforme o delito em causa ${ }^{52}$. As denúncias e demais diligências, juntamente com o requerimento do promotor, a quem cabia promover o processo por parte da justiça, eram remetidas à Mesa, para que, sendo caso, se decretasse a prisão do denunciado e consequente confisco de bens, caso este tivesse lugar ${ }^{53}$.

Cabe aqui perguntar se, à semelhança do processo secular, existia corpo do delito no foro inquisitorial? Poderia existir, mas não lhe era dada igual relevância, dado que a confissão supria a sua falta, prática não admissível no foro secular ${ }^{54}$.

${ }^{51}$ Sobre as denúncias, seus requisitos formais e a forma como se deviam registar, ver Livro II, Tit. 3; Regimento do Santo Officio da Inquisição, dos Reynos de Portugal. Lisboa: Manoel da Silva, 1640 (adiante designado apenas por Reg.).

${ }^{52}$ Os delitos em que se exigiam outras diligências eram: a solicitação (informações sobre o crédito dos denunciantes), bigamia (verificação da existência de ambos os matrimónios, por meio de certidões ou testemunhas) as denunciações de "palavras ou feitos duvidosos" (deveriam ser qualificadas), Reg., Livro II, Tit. 2, §8; Tit. 3, §4, 10, 11.

${ }^{53}$ Reg., Livro I, Tit. 6, §18; Livro II, Tit. 4, §1, 7. O breve de 1681, que permitiu o reinício da atividade processual da Inquisição, suspensa pelo papa desde 1674, mandou que o confisco passasse a ocorrer após a sentença, ver MARCOCCI, Giuseppe; PAIVA, José Pedro - História da Inquisição Portuguesa 1536-1821. Lisboa: Esfera dos Livros, 2013, p. 240.

${ }^{54}$ Vejam-se os comentários do inquisidor Portocarrero sobre o corpo do delito em FEITLER, Bruno - Da 'Prova' como objeto de análise da praxis Inquisitorial: o Problema dos Testemunhos Singulares no Santo Ofício Português in FONSECA, Ricardo e LEITE, Airton (ed.) - História do Direito em Perspetiva. Curitiba: Juruá Editora, 2008, p. 306. 
De seguida, tinham lugar as sessões de interrogatório do réu (de genealogia, in genere e in specie) sendo o réu admoestado antes de cada sessão para que confessasse as culpas que tinha, mas que lhe não eram declaradas ${ }^{55}$.

A segunda fase do processo era semelhante ao processo comum, na sua formalidade, entenda-se. Ao libelo acusatório, apresentado pelo promotor, seguia-se a resposta do réu e indicação de prova; em seguida, procedia-se à publicação da prova da justiça, podendo o réu em resposta apresentar contraditas. Se estas fossem aceites, cabia ao réu nomear testemunhas para que se procedesse à sua inquirição; colhidos os depoimentos das testemunhas nomeadas, o processo era concluso para despacho, onde se decidia, consoante a prova existente, pelo uso do tormento; ou, se proferia o assento final ${ }^{56}$.

Vejam-se as diferenças. Em primeiro lugar, a mais relevante, habitualmente designada por segredo processual: a ocultação ao réu dos nomes das testemunhas, bem como das circunstâncias de tempo e lugar do delito (indicadas no foro secular, logo no libelo acusatório). Sendo assim, a apresentação das contraditas, em que se impugnava o crédito das testemunhas, tinha à partida uma limitação que a tornava de facto num "jogo de adivinhação", uma vez que a sua aceitação pela Mesa estava dependente de o réu acertar na identificação correta das testemunhas ${ }^{57}$.

A segunda diferença radica no conteúdo e extensão da defesa. No foro inquisitorial não se podiam apresentar exceções, salvo o incidente de suspeição de ministros e oficiais do Santo Ofício, nem alegar o que apenas servisse para "embaraçar e dilatar" o processo; tão pouco, as alegações de direito se encontravam previstas ${ }^{58}$. Acresce que, até 1681, não eram admitidas testemunhas cristãs-novas, salvo "se não possam [os artigos]

${ }^{55}$ Sobre o modo como deveriam decorrer estas sessões, Reg. Livro II, Tit. 6. Existem igualmente inúmeros livros contendo formulários sobre a matéria, estipulando-se para cada delito as perguntas tipo, consoante a sessão em causa; ver, entre outros, o livro de formulários mandado fazer por D. Francisco de Castro, Arquivo Nacional da Torre do Tombo (ANTT)/ /Conselho Geral do Santo Ofício (CGSO), Livro 163.

${ }^{56}$ Todos estes passos encontram-se regulados no Livro II do Regimento.

${ }^{57}$ Podia no caso de recusa das contraditas ou da aceitação de poucos artigos ser decretada a realização de diligências oficiosas; estas tinham, porém, carácter residual. Veja-se o Reg., Livro II, Tit. 10, $\$ 12$.

${ }^{58}$ Reg., Livro I, Tit. 9, §4; Livro II, Tit. 8, §9 e Tit. 10, §2 (igualmente sobre o número de testemunhas, mais reduzido que no foro secular). 
provar por outras" 59 . Em prol do réu, previa-se a repetição da defesa, caso esta fosse considerada insuficiente, bem como a realização de diligências ex officio para prova de contraditas aceites, se o réu não houvesse nomeado testemunhas ${ }^{60}$.

Em terceiro lugar, a reinquirição das testemunhas. Embora estivesse prevista essa possibilidade no Regimento de 1640, no caso de dúvidas relativas ao crédito das testemunhas, sabe-se que na generalidade dos casos tal não era praticado ${ }^{61}$. No entanto, após o breve de 1681, a repergunta das testemunhas passou a ser obrigatória, passando a ser feita em trâmites até mais amplos do que no processo secular, dado que não se encontrava previsto que, por termo, o réu pudesse tornar as testemunhas judiciais ${ }^{62}$.

Acrescente-se, por último, que era admitido recurso por parte do réu de todos os despachos e sentenças "que tiverem dano irreparável ou força definitiva", como era o caso do não recebimento da defesa e das contraditas, e da sentença do tormento; excluía-se expressamente a possibilidade de recorrer da sentença final ${ }^{63}$.

\section{Da Prova}

É através do sistema legal de provas do processo inquisitivo que se conhecem as provas admissíveis e a forma como eram valoradas. Ora, esse sistema resultante do labor dos doutores do direito comum foi acolhido nos dois foros de que aqui se trata ${ }^{64}$.

${ }^{59}$ Reg., Livro I, Tit. 9, §5; Livro II; Tit. 10, §2. Sobre o breve, ver MARCOCCI, Giuseppe; PAIVA, José Pedro - História da Inquisição Portuguesa ..., cit., p. 240.

${ }^{60}$ Reg., Livro II, Tit. 11, §5; Tit. 10, §11.

${ }^{61}$ Reg., Livro II, Tit. 11, §3. Veja-se a este propósito a defesa desta prática por D. Francisco de Castro, na carta enviada a Felipe II em 24 de Maio de 1632 em resposta às queixas dos cristãos-novos, ANNT/CGSO, Livro 235, fl. 56.

${ }^{62}$ Tal como no foro secular os depoimentos dos defuntos e ausentes eram considerados judiciais, segundo estilo do Conselho Geral. Ver ANTT/CGSO, Livro 289, Fl. 171. Sobre o breve de 1681, MARCOCCI, Giuseppe; PAIVA, José Pedro - História da Inquisição..., cit., p. 240.

${ }^{63}$ Reg. Livro II, Tit. 21.

${ }^{64}$ Ord. Fil., Livro III, Tit. 52. Pode ver-se uma descrição do sistema usado no Tribunal da Fé, de autoria de Bartolomeu de Monteagudo em ANTT/CGSO, Livro 467 (não numerado). 
O sistema estava construído segundo uma classificação que distinguia a prova em graus: provas plenas, provas semiplenas e indícios. Entre as provas plenas temos a confissão e o duplo testemunho concordante de testemunhas legais. As provas semiplenas englobavam o testemunho singular, a fuga e a má fama. Os indícios, podendo ser veementes ou leves, eram de diversa ordem, como inimizade, ameaças, rumores, entre outros. A partir desta formulação, procedia-se a uma verdadeira "contabilização" das provas: duas provas semiplenas formavam uma prova plena; os indícios, sendo tabelados em um quarto ou um oitavo de prova, poderiam somar-se a outras provas perfazendo-se uma prova plena ${ }^{65}$.

A mais reiterada crítica feita contra o Tribunal da Fé português, prendeu-se com as condenações com base em testemunhos singulares. Apesar do Regimento estipular que em regra não se poderia prender (ou condenar) com base em testemunhos singulares, na verdade, para além das exceções previstas no próprio Regimento, recorria-se à condenação, quer com base na distinção da singularidade, quer com o recurso à soma de diversos testemunhos ${ }^{66}$.

No foro secular, embora fossem admitidos, tinham claramente um carácter excecional. O testemunho singular fazia prova no crime que punia as mulheres barregãs dos religiosos, sendo a acumulação de dois testemunhos singulares prova suficiente nos crimes de sodomia, bestialidade e molície ${ }^{67}$.

Outro ponto essencial prende-se com as testemunhas inábeis, isto é, as que não poderiam ser aceites, podendo a sua admissibilidade ser impugnada em sede de contraditas.

No foro inquisitorial apenas a inimizade era motivo de exclusão; as restantes testemunhas ditas inábeis eram admitidas, embora se considerassem diminuídas no seu crédito; defeito suprido pela sua acumulação

${ }^{65}$ GILISSEN, John - Introdução Histórica ao Direito. Lisboa: Fundação Calouste Gulbenkian, 2008 (edição original é de 1979), p. 178.

${ }^{66}$ Reg. Livro II, Tit. 4, §4. Sobre a singularidade e as críticas ao uso dos testemunhos singulares, ver LÓPEZ-SALAZAR CODES, Ana Isabel - "Che si riduca al modo di procedere do Castiglia". El debate sobre el Procedimiento Inquisitorial Portugués en Tiempos de los Austrias. Hispania Sacra LIX. 119 (2007) 243-268; FEITLER, Bruno - Da 'Prova' como objecto de..., cit.. Quanto à soma dos testemunhos vejam-se as regras detalhadas expostas por Bartolomeu de Monteagudo, ANTT/CGSO, Livro 467 (não numerado).

${ }^{67}$ Ord. Fil., Liv. 5, Tit. 30, pr.; Tit. 13, §7. 
que, embora tivesse regras, possuía toda uma aritmética muitas vezes difícil de alcançar ${ }^{68}$. Refira-se, no entanto, que o testemunho dado por parente (e quanto mais próximo mais eficaz) supria os defeitos das testemunhas (na totalidade ou parcialmente), quer da singularidade quer da inabilidade ${ }^{69}$.

Neste último ponto, o foro secular afastava-se diametralmente do Santo Ofício, uma vez que os parentes eram considerados testemunhas inábeis. Igualmente inábeis eram os escravos, os judeus e mouros em querelas entre cristãos, os desassisados, os menores de catorze anos, o inimigo capital e os presos por crimes graves, mas, diga-se que a própria ordenação que consagrava tão amplo conceito de inábil excecionava praticamente caso por caso essa mesma regra em determinadas situações ${ }^{70}$. Existem, porém, dois casos em que as testemunhas inábeis eram expressamente admitidas ${ }^{71}$. O primeiro, no crime de lesa-majestade; o segundo, na aleivosia, "maldade commetida atraiçoeiramente sob mostrança de amisade" diz a Ordenação; ora, esta descrição não configura propriamente um crime, mas sim uma conduta agravante que se poderia verificar em determinados delitos. A aplicar-se esta disposição, estava aberta a porta a uma larga admissão de testemunhos inábeis ${ }^{72}$.

É com base nesse sistema tabelado de provas que assentavam as decisões fulcrais do processo, como sejam a prisão do réu, a sentença de tormento e a decisão final.

Quanto ao encarceramento, creio que os dois foros não diferiam grandemente. Apesar de o Regimento indicar a necessidade de existência de prova "que razoavelmente pareça bastante para se proceder por ela a condenação", sabe-se que na prática tal não acontecia ${ }^{73}$. Na justiça secular a prisão do réu

${ }^{68}$ Entre as inabilidades, refira-se a má fama, a infâmia, a excomunhão, a cumplicidade, a menoridade, entre outras apontadas por Bartolomeu de Monteagudo, ANTT/CGSO, Livro 467 (não numerado).

${ }^{69}$ ANTT/CGSO, Livro 467 (não numerado) e Reg. Livro II, Tit. 4, §4.

${ }^{70}$ Ord. Fil. Liv. III, Tit. 56.

${ }^{71}$ Ord. Fil. Liv. V, Tit. 6, §29; Tit. 37, §3.

${ }^{72}$ Ord. Fil., Liv. V, Tit. 37, pr.

${ }^{73}$ Reg. Livro II, Tit. 4, §4 e 5. Veja-se o que se diz mais à frente sobre o juízo de inocência ou condenação na decisão final. 
era deixada ao arbítrio do juiz, bastando "uma prova menor do que para condenar (...) e, segundo muitos bastam conjecturas e presunções"74.

O uso do tormento visava a obtenção da confissão, a prova plena que em ambos os processos se almejava. Excecionalmente era usado in caput alienum, isto é, visando a delação de cúmplices (foi o caso de António Ferreira $)^{75}$. As regras a que obedecia encontravam-se maioritariamente e em ambos os foros, não na legislação, mas na doutrina dos doutores do direito comum, sendo por isso em tudo similares, quanto à fase em que ocorria - final da fase probatória -, pessoas excluídas, atos formais a ela associados, possibilidade de repetição, tipo de tormento, etc. ${ }^{76}$; e, no que é mais importante, os casos em que ocorria, um equilíbrio difícil de aferir entre a existência de indícios suficientes para pôr a tormento e a inexistência de prova bastante para condenar, tendo a contabilização das provas novamente um papel essencial ${ }^{77}$.

Importa ressalvar, no entanto, que a prática efetiva do tormento no foro secular esteve, pelo que se conhece, longe das cifras conhecidas para o Tribunal da Fé ${ }^{78}$.

Relativamente à decisão final, importa questionar se existia um juízo de inocência ou de culpabilidade. Creio que não. Na verdade, "entre a inocência e a culpabilidade havia um estado intermédio a que se podia

${ }^{74}$ Ord. Fil., Livro V, Tit. 117, §12. LEITÃO, Mateus Homem - Do Direito Lusitano..., cit., p. 217.

${ }^{75}$ Reg., Livro II, Tit. 14, §13.

${ }^{76}$ No foro secular veja-se: Ord. Fil., Livro V, Tit. 133 e FERREIRA, Manuel Lopes Prática ..., cit., Tomo III, p. 89-111; CABRAL, António Vanguerve - Pratica Judicial..., cit., p. 337; Na inquisição: Reg. Livro II, Tit. 14; ANTT/CGSO, Livro 467 (não numerado); PEREIRA, Isaías da Rosa - Documentos para a História da Inquisição em Portugal. Cartório Dominicano Português fasc. 18. Porto: Arquivo Histórico Dominicano Português, 1984, p. 109-112. Veja-se a síntese de MARCOCCI, Giuseppe; PAIVA, José Pedro - História da Inquisição..., cit., p. 200.

${ }^{77}$ Pode ver-se uma correspondência entre a prova existente e o tipo e grau de tormento em ANTT/CGSO, Livro 467 (não numerado).

${ }^{78}$ Assento da Casa da Suplicação de 1661 que restringe o uso do tormento aos crimes com pena de morte natural, Ord. Fil. Livro V, Tit. 133, nota; embora não existam dados para o uso do tormento em Portugal no foro secular, tudo indica que teve um carácter residual, FERREIRA, Manuel Lopes - Prática ..., cit., tomo I, p. 11; ver igualmente, HESPANHA, António Manuel - Da «Institia» à «Disciplina»..., cit.. Na Inquisição veja-se os números apresentados em MARCOCCI, Giuseppe; PAIVA, José Pedro - História da Inquisição..., cit., p. 200. 
chegar, por presunções, por difamação (...), por uma prova incompleta (...) no qual o réu não é considerado nem culpado nem inocente, senão possível culpado" e onde, por conseguinte, não era aplicada a pena ordinária, mas as extraordinárias, onde pontuavam a abjuração e as penas espirituais; daí que as absolvições fossem $\operatorname{raras}^{79}$.

No foro secular muito dificilmente se consegue aferir dessa realidade, sobretudo percetível na análise de processos concretos. Cabe dizer, no entanto, que no crime de sodomia esse "meio juízo" era previsto ${ }^{80}$.

\section{Conclusão}

A comparação efetuada entre os dois foros, embora deixando de lado um grande número de questões atinentes ao processo, permite que se faça uma reflexão sobre a natureza do processo inquisitorial, no quadro do direito penal do Antigo Regime em Portugal.

Creio que resulta claro que os institutos, figuras e mecanismos jurídicos usados nos dois foros são similares, dado que o seu substrato teórico é o mesmo, a cultura jurídica do direito comum. A existência desta cultura jurídica, combinação de direito romano e de direito canónico, deve ser realçada, pois só nesse âmbito é possível compreender como foi um importante auxiliar de interpretação e integração das normas jurídicas, mas igualmente um limite fundamental ao arbítrio judicial, tanto no foro secular como no inquisitorial ${ }^{81}$.

O processo inquisitorial, embora seguindo a estrutura formal do processo ordinário secular, e nisso se afasta consideravelmente da forma sumária,

${ }^{79}$ ALONSO ROMERO, María Paz - El Proceso Penal..., cit., p. 21, no sentido desta ser uma das características mais evidentes do sistema processual vigente em Castela na Idade Moderna. Quanto à raridade das absolvições, MARCOCCI, Giuseppe; PAIVA, José Pedro - História da Inquisição..., cit., p. 361.

${ }^{80}$ Ord. Fil., Livro 5, Tit. 13, §6.

${ }^{81}$ Também a colegialidade das decisões e a sua fiscalização constituíam um importante e significativo limite ao arbítrio dos juízes. Veja-se que no processo inquisitorial e com mais expressividade no processo sumário secular, não só as decisões eram colegiais, como existiam mecanismos de fiscalização das decisões; no foro secular através de uma ampla gama de recursos admissíveis; no foro inquisitorial, sobretudo através da vigilância efetuada pelo Conselho Geral sobre a atividade dos Tribunais Distritais. 
partilha com esta algumas características, onde a diminuição do contraditório e o carácter acentuadamente inquisitivo pontuam, sem, no entanto, ter o habitual corolário da sumariedade, a celeridade ${ }^{82}$.

No âmbito da prova, o Tribunal da Fé e o foro secular partilham o mesmo "quadro mental", mas a norma excecional do foro secular, transforma-se em regra no foro inquisitorial. Nem sempre expressamente, como é o caso dos testemunhos singulares, mas através de exceções e de formulações indeterminadas. Esta aglutinação no processo inquisitorial de um conjunto de regras previstas no foro secular a título sobretudo excecional, explica-se por a heresia ter sido configurada como crime de lesa-majestade divina, à imagem e semelhança da lesa-majestade humana, paralelismo que se deteta amiúde na doutrina e igualmente numa particularidade: apenas nesses dois delitos "atrocíssimos", os defuntos podiam ser processados ${ }^{83}$.

Mas existem algumas particularidades no processo inquisitorial. A primeira, o segredo. Não só enquanto ocultação do nome das testemunhas e das circunstâncias do delito, mas sobretudo enquanto cultura. Existia uma cultura de segredo, que não tinha paralelo no foro secular e que se encontra bem espelhada no Regimento "não há cousa em que o segredo não seja necessário" 84 . As reais consequências dessa cultura na marcha processual e, sobretudo, no que toca às normas previstas no Regimento em prol do réu, não são possíveis de alcançar sem um estudo apurado dos processos que confronte a norma com a prática.

A segunda prende-se com os efeitos da confissão. Se na justiça secular a confissão levava à condenação e à aplicação da pena ordinária (se bem que poderia ser atenuada, dado o estatuto de confitente), no processo

${ }^{82}$ Em idêntico sentido, no que toca ao predomínio da orientação inquisitiva sobre a acusatória, configurando uma bipartição processual atenuada, ver VALIENTE, Tomás - Relaciones de la Inquisicion com el aparato institucional del Estado in Gobierno e instituciones en la España del Antigo Regime. Madrid: Alianza Editorial, 1982, p. 13-35. $\mathrm{O}$ facto de se tratar de um processo formal e moroso, não permite a sua caracterização como um processo sumário, opinião sufragada por Pérez Martín para o caso espanhol, ver PÉREZ MARTÍN, Antonio - La doctrina jurídica y el processo inquisitorial in ESCUDERO, António (coord.) - Perfiles jurídicos de la inquisición española. Madrid:1989, p. 279-321.

${ }^{83}$ Bula Vergentis in senium de Inocêncio III (1199). Ord. Fil., Livro V, Tit. 6, §11. Reg., Tit. 18 .

${ }^{84}$ Reg. Livro I, Tit. $1, \S 7$. 
inquisitorial, a confissão é valorada de forma positiva e em favor do réu, levando à aplicação de penas extraordinárias. Quanto mais cedo na marcha processual o réu confessasse, mais leve seria o castigo; era, sem dúvida, a essa particularidade que se referia Manuel Álvares Pegas ao dizer que a Inquisição "castiga com brandura", dado que António Ferreira era confitente $^{85}$. Note-se, no entanto, que este regime mais benigno tinha o seu reverso da medalha na relapsia, duramente castigada pela Inquisição com as "mais graves penas"

Era o processo inquisitorial de natureza excecional? Se a excecionalidade, enquanto desvio à regra geral, se aferir em relação ao processo secular comum, então a resposta é claramente afirmativa. Contudo, não se pode esquecer que no processo penal do Antigo Regime, o processo inquisitorial não era o único com essa natureza e a exceção, por paradoxal que seja, era recorrente.

${ }^{85}$ PEGAS, Manuel Álvares - Tratado Historico ..., cit., p. 141. Particularidade já apontada em MARCOCCI, Giuseppe; PAIVA, José Pedro - História da Inquisição..., cit., p. 199.

${ }^{86}$ Reg., Livro III, Tit. 6, §2. 